\title{
SCENARIOS FOR THE DEVELOPMENT OF THE MIGRATION PROBLEM IN RUSSIA
}

Annotation: The article is devoted to the impact of migration processes on public opinion and possible solutions to the migration problem in modern Russia. Analysis and comparison of the results of sociological surveys conducted by various sociological services over the past five years has made it possible to identify the most vulnerable points in interethnic relations. Speaking about the future prospects of Russian migration policy, the authors offer scenarios for the development of the migration problem in Russia.

Migration is a very serious problem for Russia. The International Migration 2019 report by UN Department of Economic and Social Affairs states: "At the country level, about half of all international migrants reside in just 10 countries, with the United States of America hosting the largest number (51 million), equal to about 19 per cent of the world's total. Germany and Saudi Arabia host the second and third largest numbers of migrants (13 million each), followed by the Russian Federation (12 million)..." (International Migration 2019, 2019).

After the collapse of the USSR, Russia experienced numerous waves of migration. The situation has even worsened, since most migrants are not ethnic Russians and a significant part of them are Muslims. This causes national and religious tensions, which in turn contribute to the strengthening of right-wing radicals in Russia.

The purpose of this article is to analyze the main migration problems in Russia and describe possible scenarios for further developments. The main hypothesis of the article is that the migration problem is a serious challenge for the Russian state that can have both favorable and negative consequences in the economic, political and sociocultural spheres. In order to verify the hypothesis, the following research questions were asked:

1) Are migrants necessary for the economy of the Russian Federation?

2) What is the attitude of Russian citizens to the influx of migrants?

3) What measures is the Russian government taking to solve the migration problem

4) What is the most likely development of the migration situation in Russia?

The following methods were used to verify the hypothesis: sociological analysis, discourse analysis, extrapolation an institutional and legal analysis. 


\section{MIGRATION RESEARCH}

The problem of migration in Russia has been the focus of attention of researchers since the Soviet period. In particular, the famous sociologist Tatyana Zaslavskaya was the one who laid the foundation of rural migration research in the USSR (Zaslavskaya, 1970). After the collapse of the Soviet Union, ethnic conflicts in the post-Soviet space became an important topic. Theoretical problems related to ethnic communities were dealt by V. A. Tishkov (Tishkov, 1997). Sociological approaches to migration were reflected in the works of T. N. Yudina (Yudina, 2006). L. L. Rybakovskii singled out three stages of the migration process (Rybakovskiy, 2009; 2014), studied the transformation of migration processes in the post-Soviet space, and his recent works are devoted to the problem of depopulation in Russia. Zh. A. Zayonchkovskaya made a great contribution to the study of the reflection of post-Soviet transformation in migration processes (Zayonchkovskaya, 2010). Migration policy of Russia is devoted to the works of I. V. Ivakhniyk (Ivakhnyuk, 2011). The interests of A. G. Vishnevsky are concentrated on the demographic processes in Russia, the solution of which he associates with the development of labor migration (Vishnevskiy, Denisenko, Mkrtchyan, Mukomel, Tyuryukanova, 2011). V. I. Mukomel published a number of works devoted to various aspects of migration policy, as well as xenophobia and migrant phobia (Mukomel, 1997; Grigoryeva, Mukomel, 2014). Number of special publications were devoted to the legal status and financial situation of labor migrants in Russia. A separate group is the study of migration processes in Moscow and St. Petersburg (two largest Russian cities that attract migrants). Among these works it is necessary to name the theses of E. A. Ivanova (Ivanova, 2013), A. Yu. Malysheva (Malysheva, 2008), E. A. Nazarova (Nazarova, 2010). Concluding the brief review of the Russian scientific literature on migration, it should be noted that the researchers published a large number of interesting works, but the migration situation is changing so quickly that most articles and monographs become obsolete shortly after publication.

\section{THE DEMOGRAPHIC CRISIS IN RUSSIA}

One of the most condemned topics in the scientific community is the demographic crisis scenarios. Demographic downward trend is forecasted in Russia till the middle of the century. According to the medium variant of Federal State Statistics Service forecast based on the results of the 2002 population census, the population of Russia will fall to 137 million people by the year 2026. This option is grounded on the optimistic expectations of the birthrate and on the very approximate estimation of an average life expectancy. The total fertility rate growth from 1.2 child per woman in the year 2000 to 1.65 in 2025 is projected (Mukomel, Pain, 2006: 8). Besides, the total fertility rate per 1000 people will increase by the year 2015 and then will decline due to the changes in the age structure of the population $(8.7$ per mille in $2000,12.0$ per mille in 2015 and 9.8 per mille in 2025).

UN specialists' forecasts have much in common with domestic demographers' estimations and project the significant population decline in the coming 30-40 years, 
yet examine 4 possible scenarios dependent on different factors including the average life expectancy, birth rate and number of immigrants, which is illustrated in the graph below. All forecasted scenarios suggest the population decline by 2050, as shown in the table, while the decline estimations range is extremely large and vary from 8.7 to 50.8 million people (World Population Prospect: The Revision 2004).

UN specialists' forecasts have much in common with domestic demographers' estimations and project the significant population decline in the coming 30-40 years, yet examine 4 possible scenarios dependent on different factors including the average life expectancy, birth rate and number of immigrants, which is illustrated in the table below.

Table 1

Projected population growth of Russia according to the UN project, 2005-2050.

WPP 2004, all options (thousand)

\begin{tabular}{||c|c|c|c|c||}
\hline \multirow{2}{*}{ Years } & \multicolumn{4}{|c|}{ Forecast option } \\
\cline { 2 - 4 } & \multirow{2}{*}{ Upper } & Average & Lower & $\begin{array}{c}\text { With a permanent } \\
\text { Fertility }\end{array}$ \\
\hline 2005 & 143,202 & 143,202 & 143,202 & 143,202 \\
\hline 2010 & 141,420 & 140,028 & 138,639 & 139,609 \\
\hline 2015 & 140,132 & 136,696 & 133,243 & 135,487 \\
\hline 2020 & 138,654 & 133,101 & 127,458 & 130,708 \\
\hline 2025 & 136,611 & 129,230 & 121,721 & 125,635 \\
\hline 2030 & 134,772 & 125,325 & 115,953 & 120,509 \\
\hline 2035 & 133,858 & 121,679 & 110,156 & 115,270 \\
\hline 2040 & 133,885 & 118,334 & 104,314 & 109,761 \\
\hline 2045 & 134,282 & 115,098 & 98,371 & 103,999 \\
\hline 2050 & 134,532 & 111,752 & 92,358 & 98,169 \\
\hline Changes for 2005-2050 гг. & $-8,670$ & $-31,450$ & $-50,844$ & $-45,033$ \\
\hline
\end{tabular}

Source: Own work authors based on: World Population Prospect: The Revision 2004. WPP 2004 interim results, http://www.wpp.com/wpp/press/press/default.htm?guid=\%7b8cdaec5e-ad1e-4646-bc99-63c82aab5c21\%7d (03.04.2020).

All forecasted scenarios suggest the population decline by 2050, as shown in the table, while the decline estimations range is extremely large and vary from 8.7 to 50.8 million people.

2017 report of the Center for Strategic Research (CSR) and the High school of Economics (HSE) forecasts, by 2035, the natural population decline in Russia may amount to 400 thousand people, and a more pessimistic scenario and 1 million people annually. Over the next three decades, Russia may lose 14 million of people. Anatoly Vishnevsky (Institute of demography of HSE) notes that until 2007 partial compensation of natural losses of almost $70 \%$ was at the expense of the Slavic population of the former Soviet republics who moved after the collapse of the country in Russia. After 2007 , the source of compensation of the natural decrease dried up, and today the replenishment of losses of the population of Russia goes at the expense of other ethnic groups also arriving primarily from countries formerly part of the USSR. But if in the 2000 s the population continued to grow slowly, after 2012, began its decline. This continuing decline in working age population "has no precedent in the past," the report 
said (Demograficheskie vyzovy Rossii..., 2018). The report of the Center for strategic research, published in early 2018, noted the decline the share of people of working age. According to forecasts, the decline will slow in the twenties of this century, but only closer to 2030, it may stop. The total decrease in the number of the able-bodied population until 2030, according to 27 different forecasts, will amount to 11 to 13 million of people (Migratsionnaya politika: diagnostika..., 2018).

\section{IN-COUNTRY MIGRATION}

Labor shortages could be compensated for by the influx of migrants into sparsely populated cities and regions of Russia. The inflow can provide both internal migration (for example, from the densely populated Caucasus region to Siberia and the Far East), and external migration from neighboring countries. However, migration processes in Russia are significantly different from similar processes in other countries, for example, in the member countries of the European Union.

Negative trends are noted when it comes to in-country migrations. Compared to other countries Russian people are characterized to have low territorial mobility index (including a local level). Reasons are caused by high moving expenses, transport infrastructure underdevelopment, housing rental market constraints, high costs of housing and high rental prices, a low-income level of majority of people. Economic interests require migration from the European Center to the East and North. Meanwhile interregional in-country migrations from the East of the Russia to the Central region and Moscow remain the major migration direction, which exacerbates the disbalance of population distribution over the territory of Russia.

Nowadays, governmental programs aimed to provide assisting for people to move to strategically important and sparsely populated areas are launched. For instance, according to the "Far East hectare" (Federal'ny'j zakon ot 01.05.2016 № 119-FZ) law every Russian Federation citizen is entitled to obtain 1 hectare of land at the territory of the Far East Federal District, which could be used at his discretion. It is expected that present governmental initiative would stimulate region development and would positively affect its investment attractiveness, which could lead to the migration inflow to this region. However, the first results of this program are not yet encouraging. The main problem is the remoteness and harsh conditions of the region, as well as the complex bureaucratic procedures associated with the registration of property.

In-country migrations development has strategic importance for Russia, thus it should be accompanied by interethnic issues solutions, which have been recently put on the same level with national security issue and integrity of the country. Due to the great diversity of ethnics and non-Russian population prevalence, solutions to single regions of Caucus, the Republic of Ingushetia and Tatarstan call for greater focus certainly.

The prominent Russian scientist O.I. Vendina analyzes the plurality of ethnic groups in Moscow and their transformation under the impact of post-Soviet reforms in her article Cultural Diversity and Side-Effects of Ethno-Cultural Policy in Moscow (Zayonchkovskaya, 2009: 45). It was found out that the ethnic migrants settlement 
in Moscow has a pronounced territorial specificity. In contrast to New-York, London and Paris where so-called China-towns and other ethnic districts exist, which distinctive trait is the area occupying on ethnic grounds, there are no "real ethnic blocks in Moscow yet" O. I. Vendina states (Vendina, 2009: 90). It is very important to sustain this tendency because a national state development issue is greatly dependent on the cultural homogeneity of the population. The government should clearly realize the necessity of prevention of population settlement in ethnic enclaves, which could be achieved via discontinuing in-country borders between regions.

Such term as national minorities should be marginalized in favor of the Russian nationality unity formation, which could be implemented with the reducing of bureaucratic, mechanical and financial barriers for free moving within the country and incountry migration improving. Cultural features of various ethnic groups should not be isolated, moreover, they should be integrated and dispersed in different ways forming a single nationality of Russians, of citizens of the Russian Federation. It is essential to notice that migration processes should be regulated in every federal subject to prevent migrants' concentration in distinct regions and to initiate a complex migration policy development within a huge multinational country.

\section{MIGRATION FROM OTHER STATES}

Nowadays, the migratory attractiveness of Russia is rather small in comparison with other migration countries and applies primarily to citizens of the former Soviet republics. Migrants of the "first wave," which dates back to the 90s, were overwhelmingly Russian, highly qualified specialists, had higher education. After their departure, the unfavorable economic situation and conflicts in the republics of Central Asia, the Caucasus and Transcaucasia led to a significant degradation of the education system.

New generation migrants arriving to Russia relative to their predecessors are less educated, have poor knowledge of the Russian language and a lower level of professional skills. The overwhelming majority of them are labor migrants who came to Russia for temporary work.

According to the Federal Migration Service and the Ministry of Internal Affairs of the Russian Federation, 87 percent of migrants arrive in Russia from Central Asia (Uzbekistan, Tajikistan, Kyrgyzstan) and Ukraine (September 2019 data) (Yezhemesyachnyy monitoring sotsial'no-ekonomicheskogo..., 2019: 40). The total number of labor migrants in Russia is estimated only approximately because of the large number of unregistered workers. In December 2017 the president of the Federation of migrants Vadim Kozhenov stated that the share of labor migrants reaches almost $10 \%$ of Russia population. A significant number of migrants work illegally, therefore, they are difficult to calculate. According to the estimates of the Ministry of Internal Affairs, in 2017, there were 2.6 million illegal migrants. Most experts believe that there are about 4-6 million illegal labor migrants (depending on the season), as T. Shkel stressed in "Rossiyskaya gazeta" (Shkel, 2012). In large cities, the number of legal and illegal labor migrants is approximately equal. Moscow, where earnings are much higher than the average for Russia, is especially attractive for labor migrants. For Russia, a critical- 
ly important characteristic is the professional composition of migration. Russian scientists compares educational level of labour migrants: "In the Russian Federation, labour immigration from the countries of the former Soviet Union was perceived as a great benefit, since migrants knew the state language of the Russian Federation and were close to its population in their mentality. At the same time, the content of immigration flows to the Russian Federation has changed: the current generation of migrants, especially from Central Asian countries, unlike their parents, has no longer close linguistic, social and cultural ties with the host society. As a result, labor migrants who come to the Russian Federation often do not have the education necessary to work in Russia, and in many cases do not even speak Russian at a basic level" (Burda, Gerasimova, Ochacha, 2019: 188).

The peculiarity of the migration flow is that migrants mainly come to work and they are mainly engaged in low-skilled activities. The main characteristics of migrant workers in Russia are:

- poor proficiency of the Russian language;

- lack of profession and higher education;

- willingness to work in low-skilled labor, even with a diploma of higher education;

- readiness for more severe working conditions in comparison with Russians.

Thus, low qualification of migrants is one of the obstacles to the country's economic development and hinders the adaptation of migrants to Russian society.

\section{THE CONCEPT OF MIGRATION POLICY OF THE RUSSIAN FEDERATION}

Migration policy could change the negative trends in migration processes. However, it should be recognized that Russian migration policy is far from perfect. Russian official policy does not always fulfill the purposes of national strategy aims. Consequently, numerous migrants' rights violations occur, which lead to working conditions drop and exploitation degrees heightening. Undoubtedly, migrants amount directly depends on legislative changes, its tightening sometimes has destructive effect on economy and demography improving potential as well as for investments attractiveness of Russia (Ivakhnyuk, 2011: 26).

According to the ambitious targets that were announced, the country will face the difficulties of their realization, which can't be solved without additional infusion of workforce. Nowadays, Russian government aims to achieve the goal of a new migration regulation concept forming, which could meet the challenges of the modern society.

The labor migration, undoubtedly, is one of the main instruments for a population transfer and a territorial distribution, moreover the state even has a monopoly of such regulation possessing financial actives, a legislation forming prerogative and the plan of action. The creation of decent jobs, employers' compliance with the labor legislation, in case of the governmental control, and decent wages will cause the migration inflow, which can confirm the correlation between the employment and the migration inflow. 
The Russian migration legislation does not fully comply with the current and future demands of the economic, social and demographic development, with employers' concerns and a Russian society regard in general. It is focused on attracting temporary labor migrants and does not include measures stimulating a permanent settlement of migrants, providing their adaptation and integration.

The main problem of modern Russian migration policy is the lack of its conceptual clarity, the lack of clear guidelines for the future. In Russia, there is no well-founded, based on the considerations of national expediency and adopted at the official level of the idea of what Russia's need for migrants, and what is their role in the future development of Russia. We will add to this the sharp turns of migration policy and the constant reformation of legislation. This has led to inconsistent management decisions, disoriented Russian society in relation to the objectives of migration policy and lowered the cost of migration attractiveness of Russia.

Russian migration policy failed to ensure the formation of such instruments that would structure the influx of migrant workers in accordance with the structure of the demand for labor in the vocational and qualification context. As a result, against the background of a significant influx of labor migrants, there is a constantly high unmet demand for labor, and the existing qualification potential of migrants often remains unclaimed. There is inconsistency of migration policy with the overall situation on the Russian labor market.

Lately, migration situation has changed significantly due to the adoption of several laws, which are supposed to initiate a positive shift in a migration sphere. It is worth saying that public authorities have become more open and are ready for a dialogue with scientists and public, a line of electronic resources has emerged. The President's Experts Council is established; which function is to realize national projects and demography policy. One of the major Council goals is to set the course, stages, ways and forms of both the prior national projects realization and the demography policy.

Deserves special attention the Concept of Migration Policy of the Russian Federation to 2025, adopted in June 2012. The Concept required to maximise the economic benefit of labor migration. New rules gave the advantage for highly qualified foreign specialists to find a job (Koncepsiya gosudarstvennoy migratsionnoy politiki Rossijskoj Federatsii na period do 2025).

The aims of the Concept are the following:

- Providing of the Russian Federation national security, fullest protection, comfort and population welfare;

- The Russian Federation population stabilizing and sustainable growth stimulating;

- Meeting the Russian Federation economy's needs of workforce, modernization, innovative development and improving the competitiveness of economy sectors.

The objectives of the national migration policy of the Russian Federation until 2025 are identified as:

- Creation of the conditions and incentives for the permanent settlement of emigrants and particular foreign citizens groups in Russia;

- Creation of differentiated mechanisms of attraction, selection and employment of foreign workforce;

- In-country migration development support; 
- Educational migration development and academic mobility sustain;

- Implementation of the commitment to provide humanitarian assistance for forced migrants;

- Migrants' adaptation and integration support, forming of constructive interaction between migrants and a receiving community;

- Illegal migration opposition.

Some of the Concept objectives have been already realized, others are in process of implementation or approbation. Thus, the system of patenting and examination for migrants has been already initiated.

More than that, serious inroads against illegal migrations are made. Russian legislation acts against the illegal migration, improving organizational and legal framework. Therefore, violation penalties have been increased, an accountability mechanism for employers illegally using the migrant workforce has been established, punishments for perpetrators have been severed.

\section{MIGRANTOPHOBIA}

As one of the leading experts in Russia in migration problems Zh. A. Zayonchkovskaya said, "migration is a soul of Russia" (Zayonchkovskaya, 2010) due to the fact that labor immigrants' inflow becomes important provision for successful economic, political and demographical development of Russia. However, ordinary Russian citizens strongly disagree with that thesis. The influx of migrants, especially to large cities, led to xenophobia and migrant-phobia tensions with local population. Most citizens of Russia fully disagree with the expert's opinion that migration is necessary to replenish labor resources. On this issue, there is a big gap between the expert community and ordinary citizens. A significant part of Russians are sure that the country does not need migrants at all. Negative attitudes towards migrants are increasing every year, as evidenced by three all-Russian surveys conducted by the Russian Public Opinion Research Centre (VCIOM). The surveys were conducted in 130 cities and villages. Sociologists asked respondents to express their attitude to the influx of migrants from other countries. In $200669 \%$ of respondents negatively estimated process of migration, in 2008 there were 68\% negative answers, in 2013 there were 74\%. Residents of Moscow and Petersburg are especially worried about migrants. In 2013, 84 percent of residents of Moscow and St. Petersburg negatively estimated the influx of migrants (VCIOM, 2013). About 65 percent of the capital's residents believe that the city's transportation problems are less urgent to solve than migration-related problems, Stephan Lvov, head of socio-economical research at the VTCIOM pollster, said.

Most Russians do not see the benefits of migrants for national economy. The Levada Center conducts regular sociological survey about xenophobia sentiments in Russia. The last survey was conducted between 22-28 August 2019 throughout all of Russian regions in both urban and rural settings. The survey was carried out among 1600 people over the age of 18 . The survey was conducted as a personal interview in respondent's homes. The respondents were asked: "To what degree do you agree with the following statement: Migrant work is good for the country and society." A com- 
parison of the answers for 2013 and 2019 indicates some changes. In 2013 there were $41 \%$ positive and $51 \%$ negative answers. In 2019 , respondents shared almost equally: $47 \%$ and $46 \%$ negative answers (Monitoring ksenofobskih..., 2019). However, the same survey demonstrated that $91 \%$ of Moscow residents think that "there are too many migrants" (for comparison, we note that in cities with a population of up to 100 thousand people, only $52 \%$ gave a similar answer).

Most Russians do not distinguish between migrants from the Central Asia states and migrants from the North Caucasus region regardless the fact the latter are citizens of the Russian Federation. A new term, "person of Caucasian nationality" (litso kavkazskoi natsionalnosti) has came into vocabulary of post-Soviet Russia. This describes ethnic Caucasians whose ethnic origins are linked either to the countries of the southern Caucasus or to the republics of Russia's Northern Caucasus (Chechnya, Ingushetiya and others). It should be taken in account that a negative image of ethnic Caucasians has rooted in the minds of many Russians. This problem is particularly apparent in big cities that attract the main flow of migrants.

The survey conducted by N. Shilov within the framework of the project of the network of ethnological monitoring and early prevention of conflicts by the Institute for Ethnology and Anthropology of the Russian Academy of Sciences. This survey was conducted among the residents of Moscow. Negative, neutral, and positive characteristics of migrants were identified. The negative ones are: "illegal immigrants, illegal workers, illegal hostels, underground cities, illegal residents" (54.0 percent), "fictitious registration, rubber apartments, marriage of convenience" (47.5 percent), "half-educated" (46.0 percent), "other language, ignorance of the language, different culture" (43.5 percent), "shadow economy, tax evasion" ( 43.0 percent), "unskilled manpower, army of migrants, slave labour, dubious specialists" (42.5 percent), "bribery, corruption, forged documents" (40.0 percent), "ignorance of our culture" (40.0 percent), "traders, speculators" (38.0 percent). The neutral ones are: "Ukrainians" (35.5 percent), "Uzbeks" (35.0 percent), "Tajiks" (31.5), "Azerbaijanis" (31.0 percent), and "persons from the Caucasus" (31.0 percent). Among the positive, pragmatic and rational markers (appraisals), which characterize the situation associated with migrants and their activities in Moscow, it is possible to single out the following: "reasonable regulation of migration is needed" (46.5 percent of respondents), "ethnic cuisine" (43.5 percent), "cleanliness in yards and streets" (38.0 percent), "appreciate family, large families, respect towards elders" (35.0 percent) (Shilov, 2016).

Speaking about the problems of migration in Russia, it should be noted that migrantophobia contributes to the activation of nationalist and xenophobic sentiments. Before the October Revolution of 1917, there were parties and organizations in Russia that proclaimed the slogan "Russia for Russians." The Union of Russian People (Soiuz russkogo naroda) and other so-named Black-Hundred organizations called themselves "the truly Russians" and "the patriots." In Soviet era, the Communist Party suppressed any hint of nationalism. As a result of the perestroika nationalists went out of the underground.

The first organization of its kind was the national-patriotic front Pamyat (Memory). At present, the Pamyat split into several competing groups, but it was a school for leaders of the nationalist movement. The Neo-Nazi political party "Russian National Unity" 
(Russkoe nationalnoe edinstvo, RNE) adopted a red and white swastika emblem and openly expressed admiration for German national socialism, although the organization officially denied any support for Nazi ideology. The Russian National Unity demanded the expulsion of national minorities that "have their homeland outside Russia," especially Jews and migrants from the South Caucasus. In 1999, the Moscow headquarter of the party was closed. The National Bolshevik Party (Nasionalno Bolshevistskaya partia), also known as the Nazbols, was founded by a writer Edward Limonov in 1993. Nazbol's used emblems reminiscent of Nazi emblems although they denied any links to fascism, all forms of antisemitism, xenophobia and racism. Nevertheless, the party was deemed extremist and banned by the court in 2007.

Nationalist and anti-migrant slogans were also used by legal political parties. The Liberal-Democratic Party of Russia (Liberal'no-Demokraticheskaya Partiya Rossii). The leader of the populist party Vladimir Zhirinovsky constantly declares: "I am for Russians! I'll protect Russians." Liberal Democratic Party of Russia traditionally focuses on nationalist discourse. Another shining example of anti-migrant activity was "Motherland-National Patriotic Union" (Rodina). The party was created for the 2003 parliamentary elections. The leader of the party Dmitriy Rogozin called for patriotism, nationalism, and a greater role for the government in the economy. The Rodina had some success in the elections. But then it became clear that the party was getting out of control and that radical elements were playing more important role in it. Then the project was closed after complaints that its electoral publicity contained material inciting national hatred (Kozevnikova, Shehovtsov, 2009: 78).

In 2002, In 2002, the Movement Against Illegal Immigration (Dvizhenie protiv nelegalnoi immigratsii, DPNI) was founded in reaction to ethnic violence between residents of a Moscow's suburb and immigrants from the South Caucasus and Central Asia. The leader of the organization was Aleksandr Belov (Potkin), a former member of ultra-nationalist Pamyat. According to their own statements, the DPNI acted solely against illegal migration, but the opponents accused the organization of reviving the slogan "Russia is for Russians," demanded the deportation of Chechen and other migrants. The DPNI was declared extremist by the High Court of Russian Federation and banned in 2011. The ban was of no practical significance, since Aleksander Belov, Dmitry Dyomushkin and Vladimir Basmanov immediately created an Ethnic-Political Association the "Russians" (Russkie). The Association proclaimed its goal to protect the rights and interests of the Russian population, both inside the country and beyond. The Association advocated the foundation of a Russian national state and government.

The Movement Against Illegal Immigration, the "Russians" and other organizations took part in so-called "Russian March" takes places annually on the 4th November. It is the Unity Day, a national holiday established in 2005 to replace commemorations of the Bolshevik revolution 1917. The consequences of that decision were quite unexpectable. As liberal journalists say, the government had established "Nazy day," or the day of the nationalist mass demonstration in Moscow and in other cities.

Ukrainian events has radically changed the situation. As stressed by human rights activists, "since the beginning of 2014 , the political and militant activity of Russian nationalists, along with life of Russia in general, revolved around the events in Ukraine - the Maidan, and then the war. Curtailing of the anti-migrant campaign in late 2013 
became another important factor for the nationalists. The shift of attention toward Ukraine has only reinforced the sharp decline in popularity of the anti-migrant theme - always the principal nationalist issue" (Yudina, Alperovich, 2015).

The Ukrainian crisis split the nationalists into two camps. One part of nationalists supported the "Russian Spring" the form of military activities in eastern Ukraine. The Russian National Front, the Great Russia, the Union of Orthodox Banner Bearers, Black Hundred and others have all rallied for Novorossiya project. On the other hand, "the Russians" criticized the intervention in Ukraine. They were accused by their recent allies of being followers of the ukrainian nationalist Stepan Bandera. Grassroots ultra-right nationalists even participated in military operations in the Donetsk People's Republic and Luhansk People's Republic. Surprisingly, a great number of volunteers switched to opposition positions. In particular, such a political evolution was made by Igor Strelkov (Girkin), who gained large popularity among "patriots" for his role in the war in Eastern Ukraine. Soon after returning to Russia he became a fierce critic of the government.

At present, Russian nationalists do not have any number of political organizations. Most of their leaders are arrested or isolated. The ultra nationalists don't have an access to the media. The Russian March 2017 gathered only about 400 participants - far less than in previous years. The weakness of Russian nationalists contrasts sharply with the growing influence of extreme right-wing populists in Germany, France and other EU countries facing the recent migrant crisis. Meanwhile, in Russia there is the possibility of a revanche of xenophobic and nationalist forces. The results of sociological polls testify that the slogan "Russia for Russians" does not lose its popularity.

\section{SCENARIOS FOR MIGRATION}

Despite migrantophobia Russia needs educated, highly qualified migrants. The Federal Migration Service was tasked with attracting 300,000 highly qualified foreigners per year to the country (Migratsionnaya politika, 2018: 10). The problem is that events are currently developing in exactly the opposite scenario. Russia remains unattractive to skilled workers, most labor migrants have a low level of education. Along with this, there is a phenomenon that can be called "flight of hearts." Russian educated youth expresses a desire to emigrate abroad (most of them want to go to Western countries). According to VTSIOM, this figure is $26 \%$ among young people aged $18-24$. The determining factor for those wishing to go abroad is the desire to improve their standard of living (40\%).

At present, there is no consensus among decision makers at the state level and among the Russian expert community on how the state migration policy of Russia should develop, and whether it makes sense at all to build a migration strategy in the context of the changing migration situation. Therefore, speaking about the future prospects of Russian migration policy, the following options (scenarios) of developments can be identified.

"Inertial" scenario. This scenario is based on the conceptual premise that it is pointless to build a migration strategy at all, since migration processes are volatile and 
unpredictable. The state has the role of controller, whose task is to ensure the legality of the entry, stay and employment of migrants by available methods. This scenario assumes that migration policy will follow the migration situation, and will not pretend to form migration trends desirable for the state and society. In many respects, this is an "inertial" scenario that enshrines the existing model of migration policy.

"Barrage" scenario. This scenario implies a tightening of migration policies for both permanent and temporary migrants. The possibility of such a scenario is currently more than great. This is also supported by the fact that, according to various sociological studies, the overwhelming majority of the Russian population is in favor of tightening the policy on the influx of migrants. The implementation of this scenario will reduce and narrow the channels of entry of temporary and permanent migrants and will have rather negative consequences for the prospects of socio-economic development of Russia. This may result, in particular, in a shortage of labor in the Russian labor market, a decrease in the competitiveness of Russian enterprises, a slowdown in Russia's economic development, an increase in unregistered migration and illegal employment, and an increase in the demographic burden on the working population.

"Economic» scenario". The essence of this scenario is to focus migration policy solely on receiving immediate economic dividends from international migration. According the "economic scenario," since the main beneficiary of the use of the migration resource is the Russian economy (business, public and private enterprises, employers experiencing a shortage of labor), all efforts of the state should be focused on ensuring the maximum economic benefit from migrants. This is a kind of "policy of luring" highly qualified personnel. In its context, foreign graduates of Russian universities, the vast majority of whom are citizens of the CIS republics, are considered only as a promising resource for replenishment of the Russian labor market. Preferences in obtaining a residence permit and Russian citizenship are created for them. Implementation of this scenario is fraught with serious tension in Russia's relations with its neighbors and partners, certain foreign policy, geopolitical and economic risks and complications.

The Russian labor market, while maintaining the current model of attracting foreign labor, allowing for the existence of a significant segment of undocumented employment of migrants, faces deformation of its structure, degradation of labor relations, widespread practices of discrimination and exploitation of workers. Taking into account these factors, the number of foreign citizens coming to Russia, mainly from the CIS countries, is still expected to be consistently high in the coming years. At the same time, some of the migrant workers, as a result of the deterioration of economic situation and loss of income, will either travel to their countries of permanent residence, or try to compensate for the loss of their income by evading payment of advance payments under the patent, or by complete departure "in the shadow."

In the coming years, Russia is also likely to continue the trend of further outflow of Russian citizens with a high educational and qualification level, against the background of the inflow of low-skilled foreign labor into the country. In turn this will lead to a further decrease in the quality of the labor force involved in the Russian labor market and act as a brake for the innovative development of the Russian economy. 
1. The difficult demographic situation in Russia makes it necessary to attract migrants. Such a policy contributes to economic growth, but at the same time carries the danger of serious risks caused by the influx of people of a different culture, religion and mentality into the country. It is an extremely difficult process. In this respect, Russia can be cautioned by the negative example of other states that have failed to fully solve the problem of integrating migrants into the host community.

2. As all sociological polls show, the majority of Russian citizens are seriously afraid of an influx of migrants, especially from the Caucasus and Central Asia. Neither the arguments of specialists, nor the propaganda of tolerance in the state media, in schools, etc. do not have the desired impact. In this respect, Russia follows the path of European countries, where after the migration crisis of 2015, an increase in migrant phobia was noted.

3. The government of the Russian Federation is at a crossroads. On the one hand, the government goes to meet the interests of business, which is interested in cheap labor. Anti-immigration conflicts are hushed up in the loyal media. The activities of Russian nationalist groups are prohibited, their leaders are in political isolation. On the other hand, officials are aware of the danger of uncontrolled migration to the security of the Russian Federation. In this regard, the government has recently been making efforts to streamline migration processes, limit the influx of unskilled workers, and adapt migrants to Russian realities.

4. Answering the question which of the three scenarios given in the article is the most probable, it should be emphasized that most likely we will be faced with a combination of all three scenarios. As already noted, the "Inertial" scenario is essentially a simple description of Russian migration policy in the recent past and, in part, at present. The "Barrage" scenario runs counter to the interests of economic development. However, the history of Russia shows that the economy is often sacrificed to politics and ideology. The "Economic" scenario is the most favorable for the development of the economy, but the prospects for this scenario cannot be called cloudless given the political confrontation with the West. In addition, it should be taken into account that the implementation of any scenario depends not only on the political and economic situation in Russia, but also on the situation around the world. It all depends on the economic and political situation in the country, as well as on the situation in the whole world. Unexpected events, such as the coronavirus epidemic, can lead to a global recession that will fundamentally change the labor market in Russia and other countries, undermine globalism and stimulate xenophobic sentiments.

\section{REFERENCES}

Burda M., Gerasimova I., Ochacha M. (2019), Migration policy as instrument of ensuring national state security, "Przegląd Strategiczny”, No. 12, https://doi.org/10.14746/ps.2019.1.12.

Demograficheskie vyzovy Rossii (2018), Center for strategic research, Moscow, https://www.csr.ru/ news/demograficheskie-vyzovy-rossii/ (01.04.2020). 
Demographic modernization of Russia, 1900-2000 (2006), (ed.) A. G. Vishnevsky, Novoye izdatel'stvo, Moscow.

Federal'ny’j zakon ot 01.05.2016 № 119-FZ - “Ob osobennostyax predostavleniya grazhdanam zemel'ny'x uchastkov, naxodyashhixsya v gosudarstvennoj ili municipal'noj sobstvennosti i raspolozhenny'x na territoriyax sub'ektov Rossijskoj Federacii, vxodyashhix v sostav Dal'nevostochnogo federal 'nogo okruga, i o vnesenii izmenenij votdel 'ny'e zakonodatel 'ny'e akty'Rossijskoj Federacii."

Grigoryeva K. S., Mukomel V. I. (2014), Migranty i rossiyane na rynke truda: usloviya, rezhim truda, zarabotnaya plata, at: Migranty, migrantofobii i migratsionnaya politika, The Moscow bureau on human rights, Moscow.

International Migration 2019 (2019), in: Report by UN Department of Economic and Social Affairs Population Division, New York, https://www.un.org/en/development/desa/population/migration/publications/migrationreport/docs/InternationalMigration2019_Report.pdf (03.04.2020).

Ivakhnyuk I. V. (2011), Perspektivy migratsionnoy politiki Rossii: vybor vernogo puti, MAKS Press, Moscow.

Ivanova E. A. (2013), Vozmozhnosti i perspektivy noveyshikh informatsionnykh tekhnologiy v regulirovanii migratsionnoy politiki Rossiyskoy Federatsii, RUDN University, Moscow.

Koncepsiya gosudarstvennoy migratsionnoy politiki Rossijskoj Federatsii na period do 2025 goda, http://www.kremlin.ru/acts/15635 (25.04.2020).

Kozevnikova G. V., Shehovtsov A. V. (2009), Radikalny russkiy nacionalizm: strukuri, idei, lica, Centr ,Sova”, Moscow.

Malysheva A. Yu. (2008), Trudovaya migratsiya v stolichnom megapolise i mekhanizmy yeye regulirovaniya, Moscow.

Migration and the 2030 Agenda. A Guide for Practitioners (2018), International Organization for Migration, Geneva, https://publications.iom.int/books/migration-and-2030-agenda-guidepractitioners (20.07.2020).

Migratsionnaya politika: diagnostika, vizovi, predlozenia (2018), Center Stratedicheskih Razrabotok, https://www.csr.ru/upload/iblock/e4b/e4b41353159a34f48cddd3c1effble41.pdf (20.07.2020).

Monitoring ksenofobskih nastroenij v 2019 godu, https://www.levada.ru/2019/09/18/monitoringksenofobskih-nastroenij-2/ (01.12.2019).

Moscow Mayor says no to more mosques in the city, "Russia Today", 01.03.2003, https://www. rt.com/russia/moscow-mayor-says-no-to-more-mosques-in-the-city-669/ (01.12.2019).

Mukomel V. I. (1997), Pravovyye osnovy i praktika regulirovaniya migratsii v subyektakh Federatsii, „Migratsiya”, Vol. 3.

Mukomel V. I., Pain E. A. (2006), Nuzhny'li immigranty'rossijskomu obshhestvu, Fond “Liberal'naya missiya", Moscow.

Nazarova Yu. A. (2010), Vneshniye migranty v Moskve i ikh vliyaniye na sovremennyye sotsial'nyye protsessy, Moscow.

Osadchaya G. I., Yudina T. N. (2009), Migratsionnyye protsessy i migratsionnaya politika Moskvy, RGSU, Moscow.

Postsovetskiye transformatsii: otrazheniye v migratsiyakh (2009), (eds.) Zh. A. Zayonchkovskaja, G. S. Vitkovskaja, Tsentr migratsionnykh issledovaniy, Institut narodnokhozyaystvennogo prognozirovaniya RAN, IT „Adamant”, Moscow.

Programma “Dalnevostochnyy gektar”, https://надальнийвосток.рф/ (23.07.2020). 
Russian Public Opinion Research Centre (VCIOM), Muscovites worried about migrants - survey, https://wciom.com/index.php?id=63\&uid=776 (01.02.2020).

Rybakovskiy L. L. (2009), Transformatsiya migratsionnykh protsessov na postsovetskom prostranstve, Moscow.

Rybakovskiy L. L. (2014), 20 let depopulyatsii v Rossii, Econ-Inform., Moscow.

Shilov N. V. (2016), Migrant phobia as a risk factor for the occurrence of interethnic conflicts, "Regionology Journal", No. 4.

Shkel T. (2012), Arifmetika migratsii, "Rossiyskaya gazeta", 22.03.2012, http://www.rg.ru/ 2012/03/22/migranty.html (15.05.2017).

Tishkov V. A. (1997), Ocherki teorii i politiki etnichnosti v Rossii, Moscow.

Vakulenko Y., Leukhin R. (2016), Diskriminiruyutsya li inostrannyye rabotniki na rossiyskom rynke truda?, „Ekonomicheskaya politika”, Vol. 11(1).

Vendina O. I. (2009), Kul'turnoye raznoobraziye $i$ "pobochnyye» effekty etnokul'turnoy politiki $v$ Moskve, „Immigranty v Moskve” (ed.) Zh. A. Zayonchkovskaya, Moscow.

Vishnevskiy A. G., Denisenko M. B., Mkrtchyan N. V., Mukomel V. I., Tyuryukanova Ye. V. (2011), Tolerantnost kak faktor protivodeystviya ksenofobii: upravleniye riskami ksenofobii v obshchestve riska, Academic Publishing, Moscow.

World Population Prospect: The Revision 2004. WPP 2004 interim results, http://www.wpp.com/ wpp/press/press/default.htm?guid=\% 7b8cdaec5e-ad1e-4646-bc99-63c82aab5c21\%7d (03.04.2020).

Yezhemesyachnyy monitoring sotsial'no-ekonomicheskogo polozheniya $i$ samochuvstviya naseleniya sentiabr 2019, Rossiyskaya akademiya narodnogo khozyaystva i gosudarstvennoy sluzhby (RANKHIGS), https://www.ranepa.ru/images/insap/insap/Monitoring_16_09_2019.pdf (03.03.2020).

Yudina N., Alperovich V. (2015), Calm Before the Storm? Xenophobia and Radical Nationalism in Russia, and Efforts to Counteract Them in 2014, http://www.sova-center.ru/en/xenophobia/ reports-analyses/2015/04/d31818 (01.04.2020).

Yudina T. N. (2006), Sotsiologiya migratsii, Akademicheskiy Proyekt, Moscow.

Zaslavskaya T. I. (1970), Migration of the rural population, Mysl', Moscow.

Zayonchkovskaya Zh. A. (2009), Immigranty'v Moskve, Institut Kennana, “Tri kvadrata”, Moscow.

Zayonchkovskaya Zh. A. (2010), Migraciya - e'to dusha Rossii, http://academ.info/news/15340 (01.04.2020).

Zayonchkovskaya Zh. A., Tyuryukanova Ye. V. (2010), Migratsiya i demograficheskiy krizis v Rossii, Moscow.

\begin{abstract}
The article is devoted to the impact of migration processes on public opinion and possible solutions to the migration problem in modern Russia. An analysis and comparison of the results of sociological surveys conducted by various sociological agencies over the past five years has made it possible to identify the most vulnerable points in interethnic relations. Speaking about the future prospects of Russian migration policy, the authors offer scenarios for the development of the migration problem in Russia. To study the experience of the organization, as well as to determine the specific features of the functioning of the migration process, comparative methods are used to identify the main ways of regulating the migration policy in Russia and
\end{abstract}


to compare this practice with international experience. The generalization method is also used, allowing the authors to identify common properties and characteristics of the objects of study by moving from a particular or less general concept and judgment to a more general concept or judgment within the framework of this study. The methods of induction and deduction are widely used in academic research. Thanks to these methods, researchers have the opportunity to examine certain processes in detail, build logical relationships and sequences, and identify patterns. The use of induction made it possible to derive general propositions from a series of particular statements and isolated facts based on data from past experience.

Keywords: Migrants, migration, Russian migration policy, international migration, discrimination, illegal immigrants

\section{SCENARIUSZE ROZWOJU PROBLEMU MIGRACJI W ROSJI}

\section{STRESZCZENIE}

Artykuł poświęcony jest wpływowi procesów migracyjnych na opinię publiczną i możliwym rozwiązaniom problemu migracyjnego we współczesnej Rosji. Analiza i porównanie wyników badań socjologicznych przeprowadzonych przez różne instytucje socjologiczne w ciągu ostatnich pięciu lat pozwoliły określić najbardziej wrażliwe punkty w relacjach międzyetnicznych. Mówiąc o perspektywach rosyjskiej polityki migracyjnej, autorzy proponują scenariusze rozwoju problemu migracyjnego w Rosji. W celu zbadania doświadczeń organizacji, a także określenia specyfiki funkcjonowania procesu migracji, zastosowano metody porównawcze, które pozwoliły zidentyfikować główne sposoby regulowania polityki migracyjnej w Rosji i porównać tę praktykę z doświadczeniami międzynarodowymi. Zastosowano również metodę uogólnienia, w wyniku której autorzy określili wspólne właściwości i cechy obiektów badań, przechodząc w ramach niniejszego opracowania od pojęcia i osądu konkretnego lub mniej ogólnego do bardziej ogólnego. Metody indukcji i dedukcji są szeroko stosowane w badaniach naukowych. Dzięki tym metodom badacze mają możliwość szczegółowego zbadania określonych procesów, zbudowania logicznych relacji i sekwencji, oraz wyznaczenia schematów. Zastosowanie indukcji umożliwiło wyprowadzenie ogólnych propozycji z szeregu konkretnych stwierdzeń i pojedynczych faktów opartych na danych z przeszłych doświadczeń.

Słowa kluczowe: migranci, migracja, rosyjska polityka migracyjna, migracje międzynarodowe, dyskryminacja, nielegalni imigranci 